\section{Extensão Cultural: Literatura, artes visuais e formação de professores}

Coelho Lastória, A. y otros (2016).

São Paulo: FUNPEC Editora. 188 páginas

Reseñado por Daniela Lima Nardi Gomes

Universidade de São Paulo. Brasil

dany_nardi@usp.br
Integración de la docencia y la extensión /

Reseña de libros

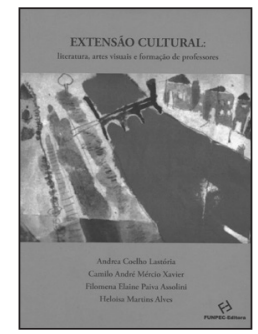

O livro Extensão Cultural: Literatura, artes visuais e formação de professores, lançado no ano de 2016, pelos professores Andrea Coelho Lastória, Camilo André Mércio Xavier, Filomena Elaine Paiva Assolini e Heloisa Martins Alves é um dos produtos resultado do Projeto "Ribeirão Cultural" e da "Incubadora Cultural". Ambos vinculados à Faculdade de Filosofia, Ciências e Letras de Ribeirão Preto, da Universidade de São Paulo, com apoio da Faculdade de Medicina da mesma universidade e da Fundação de Pesquisas Científicas de Ribeirão Preto - FUNPEC -RP. Os referidos projetos envolveram uma parceria inédita entre a Universidade de São Paulo e a Escola Estadual "Otoniel Mota", de Ribeirão Preto, São Paulo, Brasil.

Composta por 188 páginas, a obra é dividida em quatro seções, sendo a primeira, Ensaios Teóricos, composta por três capítulos teóricos, Formação inicial continuada de professores: O professor como pesquisador e a pesquisa colaborativa, Formação inicial de professores: Pela valorização dos saberes docentes e Artes visuais, imagens e leituras na educação escolar: Uma abordagem discursiva. A segunda seção, Produções Poéticas, traz poemas e crônicas escritas por alunos e professores do Ensino Médio, da Escola Estadual "Otoniel Mota". A terceira seção apresenta depoimentos de alguns dos participantes do Projeto Incubadora Cultural. A quarta e última seção, Entrevistas, traz uma interlocução entre entrevistados e entrevistadores sobre a trajetória e interesse pela arte de renomados artistas plásticos.

A realização desta obra é o resultado da produção coletiva como meio de divulgação dos saberes científicos e escolares desenvolvidos na prática pedagógica por meio de formação continuada de professores. Os projetos Ribeirão Cultural e Incubadora Cultural, em parceria com a Escola Estadual Otoniel Mota, tendo como tema o amor, fortificaram e incentivaram a produção literária e de artes visuais por alunos e professores. A relevância de um trabalho com essa dimensão é o diálogo entre a extensão, a docência e a pesquisa científica. Por meio de uma integração entre essas frentes, dá-se voz aos atores do processo ensino-aprendizagem: alunos e professores, tendo como base a produção de saberes que ocorre no cotidiano das práticas escolares. A universidade sai de seus domínios e adentra a escola, enxergando o professor como um pesquisador, e convidando-o a partir da ação, passar pela reflexão e retornar à ação de maneira mais rica e reflexiva.

A literatura e as artes plásticas foram os campos que possibilitaram as trocas e experiências, demonstrando a importância da leitura do mundo e da leitura da imagem, como formas de sensibilizar os educandos e ampliar sua relação com a realidade à sua volta, em um processo de construção da cidadania e da criticidade.

Extensão Cultural: Literatura, artes visuais e formação de professores é uma obra que nos convida a refletir sobre a relevante parceria entre universidade, escola e sociedade, por intermédio de um projeto envolvente, que toca e sensibiliza alunos, professores e leitores. 